\title{
Innovation in Repackaging Can Change the Whole Perception on the Product
}

\author{
Zoha Raza \\ Research Scholar \\ Karachi University Business School, University of Karachi, Pakistan \\ Dr. Danish Ahmed Siddiqui \\ Associate Professor \\ Karachi University Business School, University of Karachi, Pakistan
}

\begin{abstract}
The objective of this study is to determine whether innovation in repackaging changes the consumer perception about the product. Repackaging is analyzed through Change in Color, Change in Background Image, Innovation, Change in Quality, and Change in Size. A sample of 300 respondents has been collected through questionnaire and tested for reliability of the model. According to the finding of the research study, it has been observed that the repackaging is the most important factor by which a product perception can be changed easily in the mind of consumers It is further concluded that the repackaging elements like its color, Packaging Quality, back ground image of wrapper, and innovation are more important factors when building or changing the existing perception of product. The results have also revealed that changing size of packaging can negatively influence on customer's perception. Finally, it has also been concluded that the Repackaging is one of the most important and powerful factor, which influences the change in consumer's perception
\end{abstract}

Keywords: Repackaging, Reliability, Innovation, Product perception, Packaging quality, Customer perception. DOI: $10.7176 / \mathrm{JMCR} / 54-04$

Publication date:March $31^{\text {st }} 2019$

\section{INTRODUCTION:}

\section{BACKGROUND TO THE STUDY}

For decades Packaging was only defined as the container of the product which is used to convey the product to the consumer safely. Traditionally the most important function of a package has been to guard the product from whatever might occur to it or whatever it might be exposed to throughout the transfer and handling. At the most fundamental level, packaging in the customer product market household serves the double purpose of storage and conservation, but now the role of packaging has modified thanks to increasing ever-changing consumer's buying behavior. Packaging now presents additional functionalities, comprising dispensing, aesthetic appreciation, subunit allotment, and secondary utilization. Firm's interest within the package as a tool of publicity is growing progressively. Packaging also helps in stimulating impulse buying behavior of product, it helps consumer to attract at a particular brand.

By repackaging the seller tends to attract the consumer towards its product amongst all the other competitive products in the market. It creates a different sense of attraction towards the product hence increasing the sale. The functionalities of repackage methods have been developing alongside with the technological complexity that has developed to meet the demand for expediency. One major example is the dispensing and quantity mechanisms that have been planned into health care products and drink containers. Item package systems can be designed for onetime use or numerous utilization purposes. Package design has been resolved to be one of the primary factors in the shoppers purchase choice. In the retail environment, packaging speaks to one of the primary purposes of contact between the product and purchaser. The shopper builds up an impression of the item dependent on the package's introduction, which could possibly prompt a sale. Packaging can go about as a voiceless sales rep that projects an image, purpose, and usefulness of the item.

In today's era repackaging is considered as an expensive method of delivering a product which increases the cost of said product making it less efficient. Consumers focus on the packing as well as on the cost of the product before purchasing, even with an outstanding packing but a high cost it won't attract the consumers. In coming years' new ways and techniques are to be developed to bring cost effective repackaged item in the market to please the consumers. So that a well presented product is displayed with reasonable pricing.

\subsection{PROBLEM STATEMENT}

Package draws in customer's attraction regarding specific brand, improves its image, and influences shopper's perception regarding the product (Rundh, 2005). Also, package gives unique incentive to the product, works as an instrument for differentiation, i.e., encourages buyers to pick the product from wide scope of comparative products, stimulates clients purchasing behavior (Underwood, Klein, and Burke, 2001; Silayoi and Speece, 2004). 
Despite the enhance in point-of-purchase choices heightening the communication potential of product packaging, empirical study facilitates on understanding whether packaging traits create customer's successive product and brand perceptions and evaluations is scant (Edward et al., 2013). Furthermore, studies have revealed that there is no conformity on categorization of package attributes. Some of researchers try to examine all possible essentials of package and their impact on customer's buying decision, at the same time as others focus on separate elements of package and their sway on customers buying (Getie Andualem Imiru, 2017). Furthermore, few researchers examine impact of package and its elements on customer's overall buying decision (e.g., Underwood et al., 2001), while others - on each stage of customer's decision making method.

Marketers are continuously being confronted with new difficulties in consumer market. Enduring major changes in the economy, in addition to growing competition from private brands, is a significant challenge. The present repacking model was built up to test whether repackaging play a vital role in changing customers perception about a particular product. This study is all about investigating if a product has bad image in the market and company is about to end the production, can repackaging and change in advertisement strategies save the day? Can repackaging be a stop-hole to bad consumer perception and turns it in to the good one.

\subsection{GAP ANALYSIS}

Muhammad A \& Kamran A, (2014) inspected the impact of packaging components on customer buying behavior and to identify how packaging elements effects on customers buying behavior. This research has included both the visual and verbal components of packaging as prior researches either focused on visual and aesthetics components of packaging or have focused independently on every verbal components of packaging (Rundh, 2013). (Nawaz A, 2012) explored which components of product packaging are the most important and how they impact customer buying behavior. This research was done keeping in view the significance of product packaging and the huge impact it can make on the purchase decision, after researching different aspects and elements of packaging. (Andualem G., 2017) inspected the effect of packaging attributes on customer buying choice behavior. Outcome shows that the use of deprived packaging could effect in causing a product failure in the market. It is essential to set suitable standards to packaging and to implement the standards accordingly for improved marketing and sales of a product. However, it focuses only on main Ethiopian commercial cities.

Review of the systematic literature shows that previous researches done on packaging was scattered, which included limited material about packaging, the elements of Packaging and how they affect the consumer behavior typically. The Gap which was found between the researches was that they didn't included the perception of quality that consumers gets through packaging. They didn't consider that the packaging is in fact a tool that tells the customer about the quality of the product, create a perception about the product and conveys particular segment which manufacturer wants to target. So it is a fact that packaging tends to change consumer behavior. Moreover, no one in Pakistan have worked on innovation in repackaging and its impacts. Repackaging is a relatively new concept and now a days, frequently used in changing brand perception. Repackaging is a new packaging of the product with another theme or innovation to attract consumers. This research has filled the gap by combining all the possible and generally accepted repackaging elements which also includes the visual elements of packaging. Additionally, this has explicitly focused about the repackaging components of FMCG industry that was not explored before.

\subsection{Research Objectives and Significance}

This research is about how retailers can use repackaging as a manufacturing tool. As consumer's first interaction with the product is when they are placed on a shelf and only better merchandising of the product can win a place in customer's basket. But this research is not focusing on how to merchandise the product to attract customer, its main purpose is to find out whether repackaging of existing product in the market. Is it possible that, not base on previous experience customer just get attract towards the innovation in packaging or it's repackaging and ends up buying that product? If it is so it means that repackaging changes the perception of the consumer and made them successfully buy the product. In today's competitive world, everyone wants to achieve success and maintain their market presence for a long time. And if they understand how to reposition their product just by repackaging can save lots of their time, research and marketing budget. It's very common in Pakistan that the companies do have a quality product but they somehow cannot manage to attract customers and because of the modern trade trend now consumer directly communicates with the products at the point of purchase.

\subsection{RESEARCH QUESTION:}

What are the outcomes of repackaging on the buying behavior decision?

Which factors are important for the repackaging of the product?

Can repackaging could be used as a promotional tool?

How repackaging works for attracting customers? 


\section{LITERATURE REVIEW}

(Mahera Mazhar et.al, 2015) Stated in his paper that Packaging is one of the first parts of promoting, planning and plays a critical job in marketing. The research paper further stated that packaging is the last impression for buyers and they settle on acquiring choices based on item packaging which manufactured an observation in the purchaser's mind, therefore it is vital that packaging is endeavoring to secure the sale, this might be as brand values, brand image, product quality and innovations. The results demonstrate that the independent variable such as packaging colour, wrapper design, background image, and packaging innovation have appropriate relationship with the dependent variable. On the other hand, no association has been found in cases of packaging materials, font style and printed information in marketing of the products. (Bidyut Kumar Ghosh, 2016) observed that although the package design is an included constituent of the promotional mix, it is moreover a significant carrier of brand equity in the store. They found that packaging color, background image and covering design of milk product have reasonable and significant connection with the customer purchasing behavior. However, the study also reveals that the other dimensions of packaging like materials used for packaging, font size, innovative ideas in packaging etc., were found to be very weak and as such there are no such effects on customer buying behavior. (Jusuf ZEKIRI et.al, 2015) confirmed that when customer is making a decision, color plays a vital role in the process. Organizations used color to express different moods, like, blue for trust, black shows power, red shows energy, green shows balance or fresh and organic. The research further concluded that the packaging color helps consumers distinguish their most wanted brands, and for companies it helps to grab consumers' interest and attention. Randi Priluck Grossman, (1999) uncovered that purchasers lean toward specific colors in particular product classification dependent on the affiliation they have shaped in past through experience. In another study, (Misbah E, Samreen L, 2015) concluded that material of packaging is most essential for shopper on the off chance that the great quality is utilized in packaging material; at that point it will pull in purchaser. The second most essential component for purchaser is color of packaging since color. Hence it has been concluded that packaging that has alluring and engaging colors convey a point of distinction to an item and the brand can have certain color proprietorship. Getie A. I, (2017) and Asadhollahi \& Givee (2007) recommend that the package color display communicates and reflect some notable highlights and immaterial qualities of the brand. It thus implies that the color pass on extraordinary messages about the brands which at last make a remarkable selling preposition. Nonetheless, it is essential to take note of that in packaging nourishment items; the package color more often takes the color of the actual item.

A study done by (Arun Kumar Agariya, 2012) on the shape of packaging shows that customers feeling concerning the packaging is in fact transferred into how customers feel about the product and inventive shapes of packaging cut through the mess in retail stores and this type of packaging could generate an iconic brand image through its special shapes.

Deliya \& Parmar (2012) are of the view that innovative packaging enhances the worth of the goods if it meets a consumer desires. In most instance customers admits a product if its package is well innovated, thus product innovation plays an essential role in consumer decision making of FMCG products. Silayoi \& Speece (2004) draw attention that technology developed for packaging comes from the current trends in products and consumer behaviors. Packaging innovation in this vibrant environment must be Consumer oriented, meets the green marketing agenda, meet the nutritional requirements of the society, must be efficiently manufactured, and should have an extended shelf life and meet food safety requirements of the people. Silayoi \& Speece (2004) are of the view that technology that comes in with a package plays a huge role and thus creates a special form of informational component

A study done on the size trait of packaging by (Arun Kumar Agariya, 2012) illustrates that diverse packaging size is way to expand a product into fresh markets. A study done by Rundh, (2013) on consumer need of packaging demonstrates that alter in the size of household in fact alters the product size. One more research on packaging size explains that smaller packaging sizes are considered by customer of smaller family and that the big size of packaging correspond the waste of product for them (Pinya Silayoi M. S., 2004). This was also established true in another research that customer's eagerness to purchase a product rises if products are presented in smaller packages and if items have shorter expiration date then customers do not choose large package sizes (Golnesa Ahmadi, 2013). Market demand also proposes that due to smaller household's products are to be purchased in smaller packages (Rundh, 2005).

A study done by (Tobias Otterbing, 2013) on textual and pictorial constituents of packaging demonstrates that textual elements of packaging are observed if they are positioned on left side and pictorial constituents of the packaging are observed if they are positioned on the right side. This in result indicates that not only eye-catching graphics, but the proper positioning of pictorial and textual element of packaging is also required in order to be perceived by customers. Graphics help customers find the brand of their choosing by making their way through clutters at retail stores and if they do not have any strong liking of a brand then background image at least gain their interest to consider a specific product for evaluation (Pinya Silayoi M. S., 2004).

Customers can also be convinced to try the actual product through the use of graphics on packaging when the 
mixtures of different elements used in graphics and holograms such as lamination with foil of aluminum or some special kind of printing can encourage a customer to feel the product packaging and therefore making the customer to try the actual product (Rundh, 2009).

A study by Underwood (2003) recommend that the item package typography influence the brand character and identity because of various structural and visual components, including brand logo(s), color, textual styles, package materials, background image, item depictions, shapes and different components giving rich brand affiliations. Intelligibility and comprehensibility of the item package are basic ideas of the product typography generally in light of the fact that, at the point when items are displayed in the rack, the method of reasoning for package typography is to lessen time spent searching for the specific brand, by guaranteeing the client effectively finds, recognize and sees their favored brand. Hence, advertisers trust that the brand name, organization name, spot of beginning, organization address and others are vital segments of the package typography which are fundamental in pulling in consumers.

\section{Theoretical Framework:}

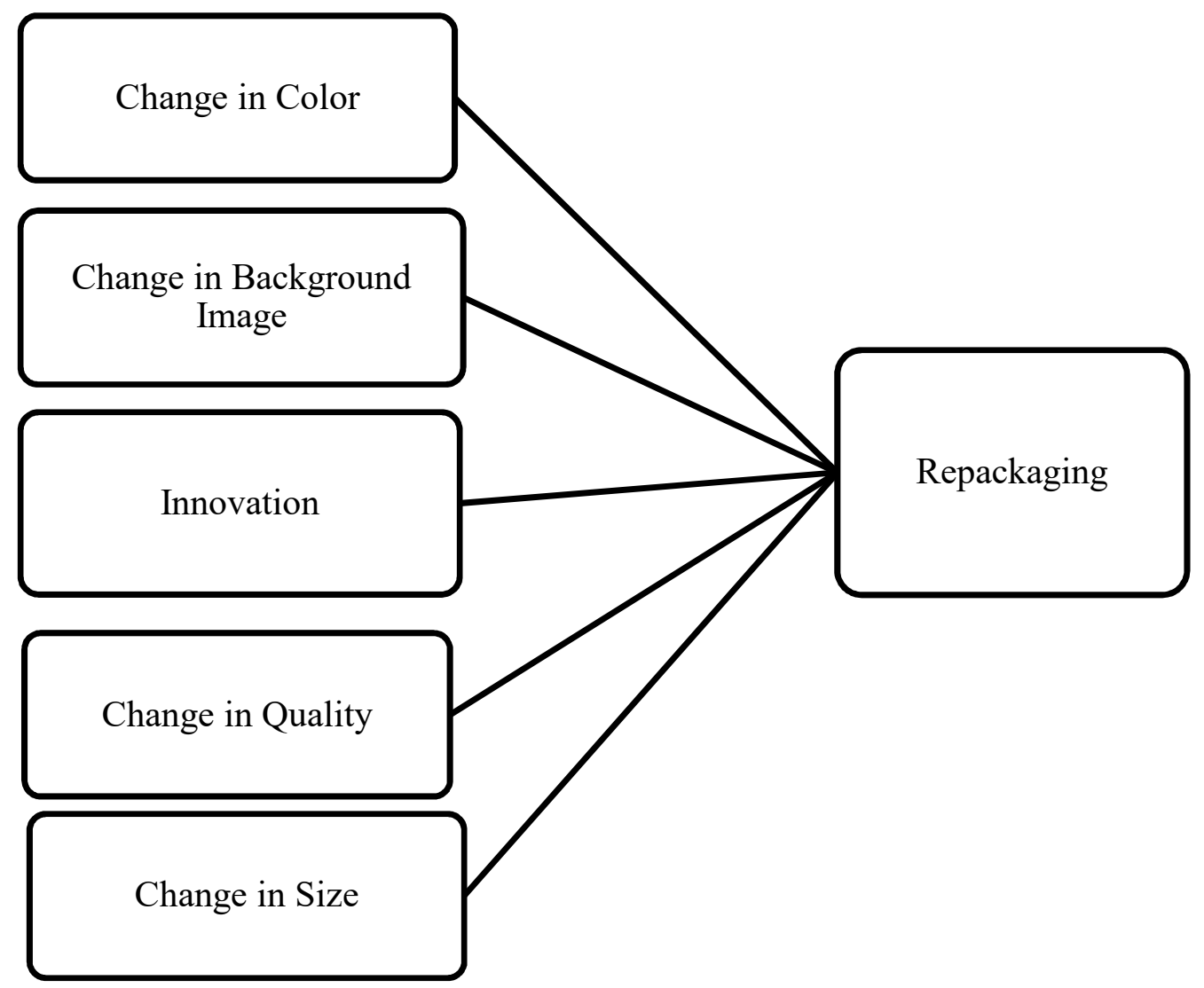

Source: Authors' own Illustration

\subsection{DEPENDENT VARIABLE:}

\subsubsection{REPACKAGING:}

Packaging has a power to attract consumer for the products or its brands, it's also influenced in consumer's perception and enhance the image of the brand (Rita Kuvykaite (2009). Packaging can use as a tools for differentiation to enhance your product within range of similar products of different brands (Wells, Farley \& Armstrong, 2007), it has a power to stimulate consumer perceptions and add unique value to the product (Underwood, Klein \& Burke, 2001; Silayoi \& Speece, 2004). Size, Quality, Color, brand image are the elements which has been evaluated for packaging and employing packaging decision earlier (Kotler (2003), while innovations founds as an important predictor for repackaging in consumer's perception.

\subsection{INDEPENDENT VARIABLES}

\subsubsection{CHANGE IN COLOR:}

Colors play very important role in Packaging (Jusuf ZEKIRI et.al, 2015), it demonstrates and communicate some intangible features and attributes of the product and brand (Asadhollahi \& Givee (2007). It means colors have 
meanings which give some message to the consumer about the product. Colors have the power to give long-lasting and unforgettable impression in consumer mind, it color has an ability to recall emotional behavior and feelings in different customer (Mutsikiwa et al., 2013; White \& White, 2006).

\subsubsection{CHANGE IN BACKGROUND IMAGE:}

Background image can enhance the level of attentiveness and level of curiosity of consumers. (Lynsey ; Laura; Armstrong; Heather, 2013). This is an essential indicator for marketers which can be made more eye-catching through the appropriate placement of elements which are related with graphics, when consumers are desiring any brand then images help them in removing the clutter and while they are not faithful to any of the brand then image act as a vital tool which can at least clutch their attention (Pinya, 2004).

Back ground image not only aids marketers in creating their product unique but also aids them in underlining their brand name more efficiently by sustaining its individuality and distinctiveness in shelves. (Smith and Taylor 2004), Images and descriptions on Packages are ground-breaking tools for: recognizing item contrasts, conveying item how it works (Meyers (1998).

\subsubsection{INNOVATION:}

Technology plays an important role in innovation of packaging (Silayoi \& Speece (2004). The innovative Packaging can increase the demands of the products in consumer, also its very helpful to fulfill consumer need (Deliya \& Parmar (2012), Well innovated products sometimes push the demands for the products in consumer, it's also highly influenced in consumer decision while they do shopping for FMCG products.

\subsubsection{CHANGE IN QUALITY:}

Packaging Quality is a considerably affecting variable to the buyer behavior. It effects the consumer's buying actions. Consumer can be interested more by great quality as compared to slight low quality. (Olson and jacoby, 1972). Packaging materials are made as per their functionality of products and the need of the consumer related with the products (Smith, 2004), Many authors previously examined material and quality as an important predictor for packaging, also different types of materials which can be used for FMCG products which impacts and derives purchase intentions for consumer (Lynsey Hollywood, 2013; Kotler, 2003; Rita Kuvykaite, 2009).

\subsubsection{CHANGE IN SIZE:}

According to the research packaging increases the amount of consumption, specifically when the product is accessible in bigger size (Kotler, 2008) moreover increase in size of packaging also directs improved quality (Smith, 2004) and stimulus the desire to consumer. (Keller, 2009), On contrast, (Arun; Ankuri; Hitesh; Udit; Deepali, 2012) added that it has been verified by the research that consumers having small families do not emphases on big size packs and treat them as surplus of product as the quantity of product will be extra than their necessities (Pinya, 2004) and if does not have lengthy reliability then consumers will not be motivated towards the bigger sizes. (Golnesa, 2013).

\subsection{HYPOTHESIS:}

H1: There is a significant relationship between Repackaging and Change in packaging color.

H2: There is a significant relationship between Repackaging and Change in back ground image of a Repackaging.

H3: There is a significant relationship between Repackaging and Innovation in Repackaging

H4: There is a significant relationship between Repackaging and Change in Quality of Repackaging

H5: There is a significant relationship between Repackaging and Change in Size of Repackaging

\section{DATA ANALYSIS:}

The information accumulated from the sample has been investigated and surveyed through the application of measurable programming like SPSS. Through the execution regression, the result of data gathered by the questionnaires was used to find out repackaging and its impact on consumer perception about product

\subsection{METHODOLOGY:}

Tools of Data Collection:

In this research Primary data collection method is used for the collection of data. In order to collect data on "Innovation in repackaging can change the whole perception of the product" we collect data by identifying 5 independent variables and 1 dependent variable, for this we use questionnaire technique to find out the results about whether repackaging can change product perception or not.

Sampling Technique and Size:

There are two main types of sampling techniques, probability sampling and non-probability sampling. We use convenience sampling, so we can find out the results on behalf of the population sample available. The sample size of our research, as we use convenience samples, is 300 questionnaires. The reason for choosing this technique is that every person uses the FMCG product and they all knows the impact of repackaging on a product.

Population:

For this research population on which tests are conducted is Karachi, Pakistan 
Measurement/Instrument:

A questionnaire will be given to the sample population to determine whether or not the repackaging of the product can change the consumer perception of the product on the basis of the given variables.

Each variable is measure by asking the questions and ratings type scale ranging from:
A, Strongly Agree b, Agree
c, Neutral
d, Disagree
e, Strongly Disagree

4.2 DESCRIPTIVE ANALYSIS:

\begin{tabular}{|l|l|l|}
\hline Latent Variables & Mean & Std. Deviation \\
\hline brand switch & 2.89 & .982 \\
new packaging & 2.16 & .890 \\
packaging reorganization & 2.46 & 1.039 \\
brand perception & 2.35 & .718 \\
CIC impacts brand perception & 2.21 & .737 \\
CIC impacts brand loyalty & 3.26 & .909 \\
CIC results in confusion & 2.14 & .920 \\
CIC result in different product & 2.47 & 1.016 \\
CIC impacts on brand image & 2.36 & .744 \\
CIBI impacts on product appealing & 2.49 & 1.129 \\
change in customer taste perception & 3.06 & 1.117 \\
image inspire to purchase product & 2.38 & 1.330 \\
frequency of CIBI & 2.90 & 1.216 \\
price expectancy & 2.20 & .803 \\
market demand of product & 2.18 & .752 \\
purchasing decision & 1.90 & .729 \\
extra value added & 2.01 & .866 \\
product quality & 2.64 & .887 \\
product price & 2.56 & .830 \\
customer attraction & 1.87 & .684 \\
buying behaviour & 2.11 & .646 \\
different SKU's & 2.22 & .727 \\
customer irritation & 2.74 & .918 \\
Valid N (listwise) & & \\
\hline
\end{tabular}

The above table shows the minimum values, maximum values, sum, mean and values of the standard deviation of all variables. The number of observations for each variable is 300 . All mean values show the central tendencies of each variable. Standard deviation values, minimum and maximum, show the dispersion of values from their mean.

\begin{tabular}{|l|l|l|}
\hline \multicolumn{2}{|l|}{ Table (2): Reliability Scores (N= 300) } & \multicolumn{1}{l}{ Cronbach's Alpha } \\
\hline \hline Variables & No of Items & 0.921 \\
\hline Repackaging & 4 & 0.824 \\
\hline Change in Color & 5 & 0.768 \\
\hline Change in Background image & 4 & 0.891 \\
\hline Innovation & 4 & 0.825 \\
\hline Change in Quality & 3 & 0.705 \\
\hline Change in Size & 3 & vare \\
\hline
\end{tabular}

The reliability of all the variables including dependent and independent variables is greater than the cut off value that is 0.70 (Table: 2) which was good (Santos, 1999). Overall Cronbach's Alpha of the questionnaire was 0.858. (Table 3) Which is significant as it is greater than the cut off value which is 0.7 . Besides purchase intention indicates 0.858 reliability which is good as it falls between the standard ranges of 0.5-0.9. Research instrument used in this study measure positive influence of Change in color, Change in background image, Innovation, Change in Quality and Change in size on repackaging

Table 3. Reliability Statistic

\begin{tabular}{|l|l|}
\hline Cronbach's Alpha & N of Items \\
\hline .858 & 23 \\
\hline
\end{tabular}




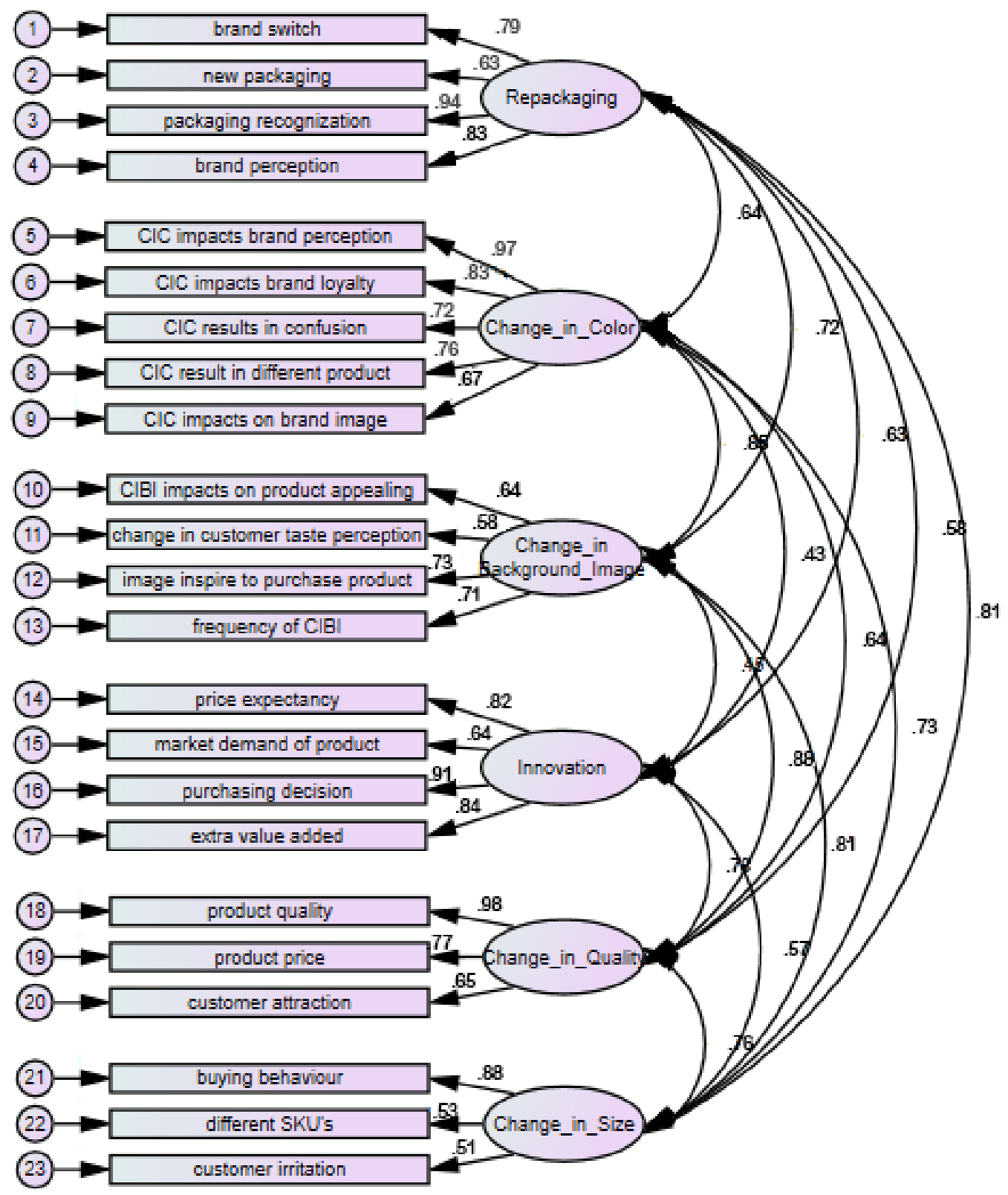

Fig. (2)

\subsection{CONFIRMATORY FACTOR ANALYSIS USING AMOS}

Confirmatory factor analysis was performed using AMOS 25. Factor analysis was employed to reduce large number of variables to extract most underlying variables called factor. Confirmatory factor analysis is a useful method to examine the variability among observed variables and excerpt variability from items and load them into a common factor. As the study entails exploratory nature, factor analysis was done to identify the most important construct 
Table (4): Standardized Regression Weights

\begin{tabular}{|l|l|l|l|}
\hline Latent Variable & Item Label & Item Description & Standardized Factor Loading \\
\hline Repackaging & Q1 & Brand Switch & 0.79 \\
\hline Repackaging & Q2 & New packaging & 0.63 \\
\hline Repackaging & Q3 & Packaging reorganization & 0.94 \\
\hline Repackaging & Q4 & Brand Perception & 0.83 \\
\hline Change in Color & Q5 & CIC impacts brand perception & 0.97 \\
\hline Change in Color & Q6 & CIC impacts brand loyalty & 0.83 \\
\hline Change in Color & Q7 & CIC results in confusion & 0.72 \\
\hline Change in Color & Q8 & CIC results in different product & 0.76 \\
\hline Change in background image & Q9 & CIC impacts on brand image & 0.67 \\
\hline Change in background image & Q11 & CIBI impacts on product appealing & 0.64 \\
\hline Change in background image & Q12 & Change in customer taste perception & 0.58 \\
\hline Change in background image & Q13 & Frequency of CIBI & 0.73 \\
\hline Innovation & Q14 & Price Expectancy & 0.71 \\
\hline Innovation & Q15 & Market demand of product & 0.82 \\
\hline Innovation & Q16 & Purchasing Decision & 0.64 \\
\hline Innovation & Q17 & Extra value added & 0.91 \\
\hline Change in Quality & Q18 & Product Quality & 0.84 \\
\hline Change in Quality & Q19 & Product price & 0.98 \\
\hline Change in Quality & Q20 & Customer attraction & 0.77 \\
\hline Change in Size & Q21 & Buying Behavior & 0.65 \\
\hline Change in Size & Q22 & Different SKU's & 0.88 \\
\hline Change in Size & Q23 & Customer Imitation & 0.53 \\
\hline
\end{tabular}

The above table shows Standardized factor loading for each item and shows the association between individual items with the extract construct. Factor loading for each item depicts reasonable to strong relationship with the underlying construct.

\section{EVALUATING MEASUREMENT MODEL FITNESS}

To evaluate the fitness of the proposed model, Amos delivers a set of useful indices that are used to determine the fitness and validity of the hypothesized model. Out of different significant indices, root mean square error of approximation (RMSEA), goodness of fit index (GFI), Chi-Square, CMIN/DF, adjusted goodness of fit index (AGFI), and comparative fit indices were observed to determine the authenticity of the research model. The discussed indices show the degree to which constructs are related to one another. Table no (5) and figure (2) demonstrate the resultant values.

Table (5): Model Fitness Test

\begin{tabular}{|l|l|l|}
\hline Model Fit & Resultant Value & Threshold \\
\hline CMIN/DF & 2.824 & $<3$ good ; < 5 Acceptable \\
\hline CFI & 0.856 & Closer to 1 ; good \\
\hline GFI & 0.926 & $>0.90$ \\
\hline AGFI & 0.902 & $>0.90$ \\
\hline RMR & 0.057 & $<0.08$ \\
\hline RMSEA & 0.068 & $<0.08$ \\
\hline
\end{tabular}

The measured values of CMIN/DF, CFI, PCLOSE GFI, RMR, and RMSEA meet the threshold and shows an acceptable model fit. However, the values of AGFI slightly differs from the standard values.

\subsection{STRUCTURAL EQUATION MODELING}

Structural equation modeling used to evaluate the structural relationship between exogenous and endogenous variables. The structural equation modeling includes factor analysis and multivariate analysis of the model. Firstly, we evaluate the model fitness and measure whether the paths showing the relationship between measured and latent variables are significant or not. The path diagram showed in figure (3). In this diagram Change in color, Change in background image, Innovation, Change in quality and Change in size towards repackaging of the product. Besides table (6) shows the model fit results by analyzing model fit indices. 


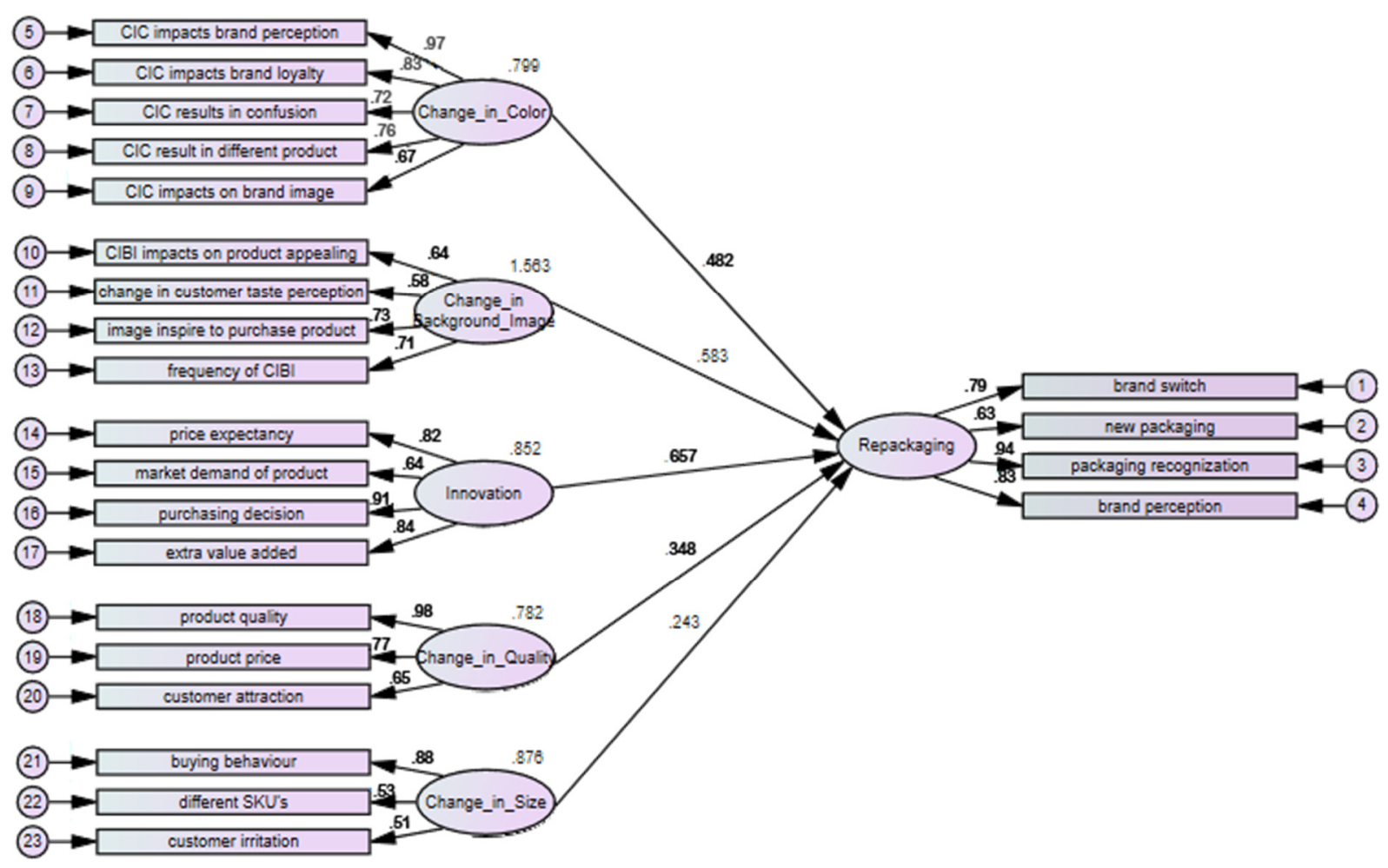

Figure (3): Path Diagram

\section{EVALUATING MEASUREMENT MODEL FITNESS}

To evaluate the fitness of the proposed model, Amos delivers a set of useful indices that are used to determine the fitness and validity of the hypothesized model. Out of different significant indices, root mean square error of approximation (RMSEA), goodness of fit index (GFI), Chi-Square, CMIN/DF, adjusted goodness of fit index (AGFI), and comparative fit indices were observed to determine the authenticity of the research model. The discussed indices show the degree to which constructs are related to one another. Table no 6 and figure 3 demonstrate the resultant values.

There are different parameters to evaluate the goodness of a fit model. The study has adopted seven model fit indices to predict model fitness. Change in color, Change in background image, Innovation, Change in quality and Change in size, were measured through 5 items and these were designed to measure Repackaging. The results of structural equation modelling depict a good fit. Comparative fit index (CFI) point up a good fit value of 0.893 by meeting the standard value, with adjusted goodness of fit index (AGFI) at 0.912 by being perfect for the threshold of 0.90 , the root mean square error of approximation (RMSEA) is 0.073 and signifies consistency of our data and a good fit.

\section{Table (6): Model Fitness Test}

\begin{tabular}{|l|l|l|}
\hline Model Fit & Resultant Value & Threshold \\
\hline CMIN/DF & 2.653 & $<3$ good $<5$ Acceptable \\
\hline CFI & 0.893 & Closer to $1 ;$ good \\
\hline GFI & 0.945 & $>0.90$ \\
\hline AGFI & 0.912 & $>0.90$ \\
\hline RMR & 0.064 & $<0.08$ \\
\hline RMSEA & 0.073 & $<0.08$ \\
\hline
\end{tabular}

The calculated value of CMIN/DFI is 2.653 which shows a good model fit. The values of CFI, RMSEA, specifies that the proposed model was statistically fit as these parameters resultant values meets threshold as explained in the table (6). 


\section{Table (7): Regression Weights (Hypothesis Testing)}

\begin{tabular}{|l|l|l|l|l|l|}
\hline & Estimate & SE & CR & P & \\
\hline Repackaging <--- Change in Color & 0.482 & 0.045 & 0.842 & .000 & H1 Accepted \\
\hline Repackaging <--- Change in Background image & 0.583 & 0.117 & 0.867 & .000 & H2 Accepted \\
\hline Repackaging <--- Innovation & 0.657 & 0.062 & 0.806 & .000 & H3 Accepted \\
\hline Repackaging <--- Change in Quality & 0.348 & 0.982 & 1.045 & .000 & H4 Accepted \\
\hline Repackaging <--- Change in size & 0.243 & 0.151 & 1.137 & .652 & H5 Rejected \\
\hline
\end{tabular}

The above table illustrate the impact of Repackaging of Change in color, change in back ground image, innovation. Change in Quality and change in Size of Product while considering repackaging of FMCG goods in Pakistan and study its impacts on customer perception. Each independent variable gives an unstandardized and standardized beta coefficient that predicts the positive or negative impact of each variable. While p-value measures significance of data at $95 \%$ confidence interval.

First, 'Change in Color' has a positively influence on 'Repackaging' $(\beta=0.482, p<.001)$, therefore H1 is accepted. Second, 'Change in back ground image' also has a positively influence on 'Repackaging" $(\beta=0.583, p$ $<.001$ ), therefore $\mathrm{H} 2$ is accepted. Third, 'Innovation' has

Positively influence on 'Repackaging" ( $\beta=0.657, \mathrm{p}<.001)$, therefore $\mathrm{H} 3$ is accepted

Fourth, 'Change in Quality' also positively influence on 'Repackaging' $(\beta=0.348, p$

$<.001$ ), therefore H4 is also accepted. Fifth 'Change in size 'was not Found a significant Positive influence on 'Repackaging' $(\beta=0.243, p>.001)$, therefore $\mathrm{H} 5$ is rejected.

\section{Discussions}

The results showed that the change in color can influence in repackaging and would play a significant role in changing the perception of the product, consumer always want something new and for brands to keep bringing changes in the product that consumer also like is so challenging so for manufacturers it is an easy way to keep customers engage with their brand just by changing color. The results were in line with (Ehsan .M, 2015, Mutsikiwa et al., 2013; White \& White, 2006) that proved Color are depictions of human thoughts, emotions and bodies. So spending on colors wisely can visually set producers apart from competitors. Colors also have the power to give long-lasting and unforgettable impression in consumer mind, it color has an ability to recall emotional behavior and feelings in different customer

This research results further clarifies the importance of the back ground image on a package. As shown in (Smith and Taylor 2004; Meyers 1998), Back ground image not only aids marketers in creating their product unique but also aids them in underlining their brand name more efficiently by sustaining its individuality and distinctiveness in shelves.

The results also showed that Innovation played very important role in repackaging and can change the whole perception of the product in the mind of the consumer. It can add value to the product, increase the market demands, Influence the purchasing decision of shopper and increase price Expectancy in a positive way for the product. This was also proved by (Deliya \& Parmar (2012) that innovative Packaging can upturn the demands of the products in consumers, also its very supportive to fulfill consumer need. It was found that innovation in Packaging is the most important element that can upturn consumer attraction towards the product.

According to the results, the change in package Quality can influence on the perception of the product image for the consumer, and it can depict a reasonable amount of improvement in product or changing its price, also quality of package to some extent attract customer while it's place on the shelf of the store. It has also been observed that consumer has this strange perception that if the Quality of container or packaging is good than the product inside the packaging or container must be so good and will surely fulfill all their desires and wants related to the product. This was further supported by (Ehsan .M, 2015; Olson and jacoby, 1972) that proved that good quality change in a packaging of a product significantly improves the sales volume.

Lastly, this research explored that the change in size can have a negative effect on the perception of the product image for the consumer, it is not good to offer too many sizes that it also sometimes irritates the customers and negatively impacts on brand and product image and can also have a negative effect on the customer's purchasing behavior related to the product. The results contradicted other studies like A.J. Arun Kumar Agariya (2012) that showed that different packaging size is way to extend a product into new markets. Or Ehsan .M, (2015), that showed that increase in size can also increase the sales volume by increasing the number of consumer who purchases a product. In contrast to the above mentioned studies this research shows the negative impact of changing the size of the packaging.

\section{CONCLUSION}

The packaging of the products plays a very important role in constructing the perception about the product, its quality and its usefulness, consumers even without knowing about the product can easily judge how good the 
product will be just by glancing on the packaging of the product. But this research focuses on the repackaging of the product. Often manufactures of FMCG do not give enough attention towards the packaging of the product, meaning behind the color scheme and the images upon the packages. They just see packaging as the container of product and thinks that it is waist of the money to spend on packaging. For these types of manufacturer, it's a difficult task to place their product in customer basket because of poor packaging, however their products with in that poor packaging is good enough than others having a good or standard packaging. This happens due to the consumer perception about the product they see placed on the shelf, so does repackaging of FMCG products change consumers mind? Will they buy the product after repackaging? And what are the key elements to consider while repackaging? These are all the key research questions that have been answered in this research report. The independent variables which can directly influence on the repackaging of FMCG products are:

Change in Color, as the color plays the most important role in grabbing the attention of shoppers 'Change In Background Image, back ground image is the first image of a product in consumers mind, as good as the image is the better consumer will perceive about the product. Innovation, in existing packaging which does not mean you have to bring a whole new technology that has never be seen, it simply means to counter the difficulties consumer are facing in handling or using a particular product. Change in Quality of Packaging, because consumers perceive the quality of packaging as the quality of the product. And Change in the Size of Packaging, it means making product available in different size of packaging to provide convenience to the customers.

According to the results obtained from SPSS, change in color positively correlates with the innovation in repackaging which means choosing a good and attractive color according to the product theme can positively influence customer's perception about the product. Similarly, change in background image, innovation in packaging and quality of the packaging all are positively related with the repackaging of product which means the better the background image the better will be the product perception in customer's mind. The more you work on customer needs satisfaction by innovating the packaging the more consumer will likely to buy the product, but the correlation between repackaging and quality of packaging are weakly correlated as compared to other which means the quality of packaging does have impact on customer perception but not too much, Last but not the least according to the results, size of packaging are negatively correlated with the repackaging which means changing sizes of repackaging confuse the customer about the package size whether it is upgraded or has been cut down it means some quality of product must have been sacrificed for it. For instant, people of Pakistan mostly think if size has been upgraded it means the quantity with in the package has been reduced or same as before but due to the big size of package they are been fooled by the company which negatively impacts on their buying decision. Similarly, if package size has been reduced, it is perceived as compromise in the quality of product. So manufactures of FMCG who are just willing to change their product perception in mind of customers are not recommended to change the size of the packaging according to the results of this research report.

This study have opened new ways on which future researches can be done, for instance all of the researches have addressed about the buying behavior of the customer non have addressed that what makes their behavior change, the reason behind the change in their behavior is due to the change in perception of the consumer related to the product due to some sort of innovations and newness of the product. This was the loop hole that was not catered before by any one in Pakistan. (Inge Ruumpol, 2014) proposed that a package's shape is a vital way for a brand to separate itself, because package design can affect customers' buying decisions. It has been observed that new things and innovations attract customers and retailers use Packaging as a marketing tool for their new product. This research main objective was to find out whether innovation in repackaging can be used as marketing and does it create a whole new perception about the product with in the market that stimulates the customer's to buy the product.

The best justification for why it is better to redesign a package professionally is because it significantly increases the paybacks. Among all one is that you can anticipate a high return on investment more rapidly and efficiently. Packaging that has strategic innovation and attractiveness can have a major existence in the marketplace and makes its brand standout from its competitors. It upturns the probability that people will purchase that product. Primarily in the repackaging, it will help in building brand loyalty, as long as the quality of your product remains steady or keeps changing towards growth. The repackaging of your product is a part of the impression and is an excessive tool for your products to sell by themselves.

\subsection{RECOMMENDATIONS:}

After the findings of the research, it is highly recommended that all FMCG companies focus on the products attractive packaging if they introduce any new product on the market. And in order to make their existing product attractive and most desirable product by the customer to purchase they should first consider about the repackaging of the product because it works as the game changer and can create a positive perception of the product in customer's mind. All the elements of packaging are positively effecting the consumer's perception except the changing in size of a packaging. For those who wants to further research on this topic can also consider other factors and dimensions of marketing as well. 


\section{REFERENCES}

Agariya, A. K., Johari, A., Sharma, H. K., Chandraul, U. N., \& Singh, D. (2012). The Role of Packaging in Brand Communication. International Journal of Scientific \& Engineering Research.

Arun Kumar Agariya; Ankur, Johari; Hitesh, K Sharma; Udit, N S Chandraul, Deepali. Singh (2012). "The Role of Packaging in Brand Communication" International Journal of Scientific \& Engineering Research, 3 (2), 113.

Asadollahi, A and Givee, M. (2011). The Role of Graphic Design in Packaging and Sales of Product in Iran. Contemporary Marketing Review, Vol. 1(5) pp. $30-34$

Bassam C. H., Mona A. D., Ghida A. C., (2018), Economic Effects of Product Packaging on Consumer Shopping Behavior: The Case of Lebanon, American Journal of Theoretical and Applied Business, 4(2):44-47.

Deliya, M. M., \& Bhaveshkumar, P. (2012). Role of Packaging on Consumer Buying Behavior-Patan District. Global Journal of Management and Business Research, 12(10).

Edward, S. T. W. (2013). The influence of visual packaging design on perceived food product quality, value, and brand preference, International Journal of Retail \& Distribution Management, 41(10), 805-816. https://doi.org/10.1108/IJRDM-12-2012-0113

Getie A. I. (2017), The Effect of Packaging Attributes on Consumer Buying Decision Behavior in Major Commercial Cities in Ethiopia, International Journal of Marketing Studies; Vol. 9, No. 6.

Golnesa Ahmadi, H. R. (2013). An Investigation of Visual Components of Packaging on Food.

Jeffrey S. Hess, L. E. Metcalf, Singh.J \& Danes.J, The Impact of Consumer Product Package Quality on Consumption Satisfaction, Brand Perceptions, Consumer Investment and Behavior, Journal of Applied Packaging Research 23-39.

Jusuf ZEKIRI, \&VjollcaVisoka HASANI, (2015). THE ROLE AND IMPACT OF THE PACKAGING EFFECT ON CONSUMER BUYING BEHAVIOUR. ECOFORUM, Volume 4(Special Issue 1, 2015), 232-239.

Keller, K. L. (2009), "Choosing Brand Elements to build Brand Equity”, Strategic Brand Management, 3rd Edition, $187-196$

Kotler, Ph. (2003) Marketing management, ( $9^{\text {th }}$ Ed.). Upper Saddle River: Prentice-Hall.

Kotler, Philip \& Keller, K. L. (2008), Marketing Management, New Jersey: Prentice Hall. Pilditch, J., 13th Edition

Kumar B. G., (2016), Impact of Packaging on Consumers' Buying Behaviour: A Case Study of Mother Dairy, Kolkata. Parikalpana, KIIT Journal of Management, 27-34.

Lynsey Hollywood; Laura, Wells; Armstrong, Gillian; Heather, Farley, (2013). "Thinking outside the carton: attitudes towards milk packaging". British Food Journal, 115 (6), 899-912.

Maliyetinin.A, (2013), Effect of Packing Cost on The Sales Price and Contribution margin, journalgülşah atağan, süleyman yükçü,13,1-9

Meyers, H.M., \& Lubliner, M.J. (1998). The marketer's guide to successful packaging design. Lincolnwood: NTC Business Books.

Mr. Mitul M. Deliya, M. B. (2012). Role of Packaging on Consumer Buying Behavior. Global Journal of Management and Business Research, 48-68.

Muhammad A. \& Kamran A. (2014), Impact of Packaging Elements of Packaged Milk on Consumer Buying Behaviour, IBAICM.

Munyarazdi Mutsikiwa, J. M. (2013). The Impact of Aesthetics Package Design Elements on Consumer Purchase Decisions: A Case of Locally Produced Dairy Products in Southern

Nawaz A. \& Mohib B. (2012), Effect of Product Packaging in Consumer Buying Decision, Journal of Business Strategies, Vol.6, No. 2, 2012, pp 1-10.

Olson, J. C., \& Jacoby, J. (1972). Cue utilisation in the quality perception process. In M. Venkatesan, Proceedings of the Third Annual Conference of the Association for Consumer Research (pp. 167 \pm 179 ). Chicago: Association for Consumer Research.

Pinya Silayoi, M. S. (2004). An exploratory study on the impact of involvement level and time pressure. British Food Journal, 106, 607-628.

Raheem R. A, Parmar.V \& Amin. M. A (2014), Impact of Product Packaging on Consumer's Buying Behavior $\begin{array}{lllllll}\text { European Journal of Scientific Research } 120 & \text { (2): 145-157. Retrieved from }\end{array}$ www.europeanjournalofscientificresearch.com

Randi Priluck Grossman, J. Z. (1999). What we know about consumers' color choices. Journal of Marketing Practice: Applied Marketing Science, 5 (3), 78-88.

Rita Kuvykaite1, Aiste Dovaliene2, Laura Navickiene3 (2009), Impact of package elements on the consumer purchase decision economics \& management.

Rundh, B. (2005). The multi-faceted dimension of packaging marketing logistic or marketing tool? British Food Journal, 107 (9), 670-684.

Rundh, B. (2007). The Multi-Faceted Dimension of Pacakging, Birtish Food Journal.107 (9), 670-684.

Rundh, B. (2009). Packaging design: creating competitive advantage with product packaging. British Food Journal, 
$111(9), 988-1002$.

Rundh, B. (2013). Linking Packaging to Marketing: how packaging is influencing the marketing strategy. British Food Journal, 115 (11), 1547-1563.

Sana. A. B (2015). Impact of Product Packaging on Consumers Buying Behavior: Evidence from Karachi. Journal of Marketing and consumer research. Retrieved from https://www.researchgate.net/publication/304497679

Santos, J. A. R. (1999). Cronbach's Alpha: A Tool for Assessing the Reliability of Scales. Journal of Extension, $37,1-5$

Silayoi, P., \& Speece, M. (2004). Packaging and purchase decisions: An exploratory study on the impact of involvement level and time pressure. British Food Journal, 106 (8), 607-628.

Smith, P R \& Taylor, J., (2004). "Packaging". Marketing Communications, London, 543-574

Tobias Otterbing, P. S. (2013). Life isn't always right: placement of pictorial and textual packaging elements. British Food Journal, 115 (8), 1211-1225.

Underwood, R. L. (2003). The communicative power of product packaging: creating brand identity via lived and mediated experience. Journal of Marketing Theory and Practice, winter, 62-76. https://doi.org/10.1080/10696679.2003.11501933

Underwood, R. L., Klein, N. M., \& Burke, R. R. (2001). Packaging communication: attentional effects of product imagery. Journal of Product \& Brand Management, 10(7), 403-422. https://doi.org/10.1108/10610420110410531

Wells, L. E., Farley, H., \& Armstrong, G. A. (2007). The importance of packaging design for own-label food brands. International Journal of Retail \& Distribution Management, 35 (9), 677-690.

White and White (2006), Advanced Art and Design, Philip Allan Updates.

Zekiri J. (2015), the role and impact of the packaging effect on consumer buying behavior, ecoforum, V: 4, special issue 1.

\section{APPENDIX}

\section{SURVEY QUESTIONS}

The following questions was used in the digital survey

\section{Repackaging:}

Q1) Would you switch your brand due to change in packaging of existing brand?

1) Strongly agree 2) Agree 3) Neither agree nor disagree 4) Disagree 5) Strongly disagree

Q2) Do you get attracted towards the existing brands due to their new packaging?

1) Strongly agree 2) Agree 3) Neither agree nor disagree 4) Disagree 5) Strongly disagree

Q3) Does repackaging of products makes it harder for the customers to recognize?

1) Strongly agree 2) Agree 3) Neither agree nor disagree 4) Disagree 5) Strongly disagree

Q4) Does repackaging of product effects the brand perception of the product?

1) Strongly agree 2) Agree 3) Neither agree nor disagree 4) Disagree 5) Strongly disagree

\section{Packaging Color:}

Q5) Does change in color of product packaging effects the brand perception of the product?

1) Strongly agree 2) Agree 3) Neither agree nor disagree 4) Disagree 5) Strongly disagree

Q6) Does change in Packaging color impacts on brand loyalty?

1) Strongly agree 2) Agree 3) Neither agree nor disagree 4) Disagree 5) Strongly disagree

Q7) Change in Packaging color of the product result in confusing the customer as different product?

1) Strongly agree 2) Agree 3) Neither agree nor disagree 4) Disagree 5) Strongly disagree

Q8) Does it feel like there is something change in a product due to the change in its package color?

1) Strongly agree 2) Agree 3) Neither agree nor disagree 4) Disagree 5) Strongly disagree

Q9) Does change in color of the packaging impact on brand image of the product?

1) Strongly agree 2) Agree 3) Neither agree nor disagree 4) Disagree 5) Strongly disagree

\section{Background Image:}

Q10) Does change in background image of the product look more appealing to the customers? 
1) Strongly agree 2) Agree 3) Neither agree nor disagree 4) Disagree 5) Strongly disagree

Q11) Change in background image of packaging can change the taste perception of a customer?

1) Strongly agree 2) Agree 3) Neither agree nor disagree 4) Disagree 5) Strongly disagree

Q12) Does the image of packaging inspire you while purchasing the product?

1) Strongly agree 2) Agree 3) Neither agree nor disagree 4) Disagree 5) Strongly disagree

Q13) Does frequent changes in background image is good to attract more customer?

1) Strongly agree 2) Agree 3) Neither agree nor disagree 4) Disagree 5) Strongly disagree

\section{Innovation:}

Q14) Does the price expectancy increases of a product due to innovations in its packaging?

1) Strongly agree 2) Agree 3) Neither agree nor disagree 4) Disagree 5) Strongly disagree

Q15) Does innovative packaging increase the market demand of the product?

1) Strongly agree 2) Agree 3) Neither agree nor disagree 4) Disagree 5) Strongly disagree

Q16) Innovation can influence the purchasing decisions of shopper while buying product?

1) Strongly agree 2) Agree 3) Neither agree nor disagree 4) Disagree 5) Strongly disagree

Q17) Innovation in packaging adds extra value according to the need and comfort of consumer?

1) Strongly agree 2) Agree 3) Neither agree nor disagree 4) Disagree 5) Strongly disagree

\section{Quality of packaging:}

Q18) Does the change in package quality depict the change in product quality as well?

1) Strongly agree 2) Agree 3) Neither agree nor disagree 4) Disagree 5) Strongly disagree

Q19) Quality change of packaging creates a perception about the change in product price?

1) Strongly agree 2) Agree 3) Neither agree nor disagree 4) Disagree 5) Strongly disagree

Q20) Quality of Packaging plays an important role in attracting customer?

1) Strongly agree 2) Agree 3) Neither agree nor disagree 4) Disagree 5) Strongly disagree

\section{Packaging Size:}

Q21) Does Change in packaging size of the product impact on your buying behavior?

1) Strongly agree 2) Agree 3) Neither agree nor disagree 4) Disagree 5) Strongly disagree

Q22) Does offering too many sizes of the product is good in term of consumer perception?

1) Strongly agree 2) Agree 3) Neither agree nor disagree 4) Disagree 5) Strongly disagree

Q23) Does change in product size and shape irritate customers while making purchasing decisions?

1) Strongly agree 2) Agree 3) Neither agree nor disagree 4) Disagree 5) Strongly disagree 